Gi respons på artikler gjennom artiklenes kommentarfelt på tidsskriftet.no.

Innleggene publiseres fortløpende på Tidsskriftets nettside og et utvalg

av innleggene publiseres også i papirutgaven i spalten «Brev til redaktøren».

Redaksjonen forbeholder seg retten til å foreta redaksjonelle endringer.

Forfattere av vitenskapelige artikler har tilsvarsrett, jf. Vancouver-gruppens regler.

\section{Re: Fra ketobemidon til morfin eller oksykodon}

J. Ræder og medarbeidere hadde i Tidsskriftet nr. 18/2016 en artikkel om utfasing av ketobemidon til bruk på sykehus til fordel for morfin eller oksykodon (1). Vi er enige $\mathrm{i}$ at ketobemidon kan erstattes med morfin eller oksykodon. Men vi vil gjerne nyansere noen momenter i disfavør av morfin.

Oksykodon og morfin anbefales i artikkelen brukt i samme dosering - enkelt og greit! Men det neves ikke at oksykodon er 30\% mer potent enn morfin (2). Doserer man likt i milligram blir effekten av oksykodon raskere og sterkere. For lik virkning må morfin doseres litt høyere.

Ræder og medarbeidere kommenterer og at «oksykodon har raskere effekt enn morfin og er derfor lettere å titrere ved akutt, sterke smerter» (1) og siterer her Lenz og medarbeidere (2). Imidlertid målte Lenz og medarbeidere smerteintensitet først etter 30 minutter. Det vanskeliggjør vurdering av anslag av analgetisk virkning. Lenz og medarbeidere skriver selv at «Although morphine is considered to be a slower acting drug, few clinical studies on this issue suggest a fairly similar time to onset (about 5-8 $\mathrm{min}$ ) and peak effect (about 20-30 $\mathrm{min}$ ) for both drugs given as IV bolus» (2).

Ræder og medarbeidere skriver at «morfin har til sammenligning, en variabel og lavere absorpsjonsgrad når det gis peroralt med henvisning til Rygnestad \& Slørdal (3) som ikke omtaler oksykodon. Morfin har lavere systemisk biotilgjengelighet som må tas hensyn til ved dosering. Det er mer usikkert om det er større variabilitet i biotilgjengelighet for morfin enn oksykodon gitt peroralt. Den interindividuelle variabiliteten av dosekorrigerte serumkonsentrasjoner av de to opioidene gitt peroralt er nokså lik for kreftpasienter (4).

Vi mener at det ikke er spesielle farmakologiske forhold som skiller oksykodon fra morfin. Morfin er vårt førstehåndsvalg.

\section{Ola Dale}

ola.dale@ntnu.no

Pål Klepstad

Torkjel Tveita

Just Thoner

Petter C. Borchgrevink

Ola Dale (f. 1948) er professor ved Norges teknisk-naturvitenskapelige universitet/St. Olavs hospital.

Ingen oppgitte interessekonflikter.

Pål Klepstad (f. 1962) er avdelingssjef ved Hovedintensiv, St Olavs hospital og professor ved Norges teknisk-naturvitenskapelige universitet. Ingen oppgitte interessekonflikter.

Torkjel Tveita (f. 1951) er overlege/professor ved Anestesi- og operasjonsavdelingen, Universitetssykehuset i Nord-Norge.

Ingen oppgitte interessekonflikter.

Just Thoner (f.1948) er overlege ved OPIN-klinikken, Universitetssykehuset i Nord-Norge.

Ingen oppgitte interessekonflikter.

Petter C. Borchgrevink (f. 1952) er avdelingssjef ved Avdeling for smerte og sammensatte lidelser, St. Olavs hospital og professor ved Norges teknisk-naturvitenskapelige universitet.

Ingen oppgitte interessekonflikter.
Litteratur

1. Ræder J, Dahl V, Markestad A et al. Fra ketobemidon til morfin eller oksykodon. Tidsskr Nor Legeforen 2016; 136: 1518-9.

2. Lenz H, Sandvik L, Qvigstad E et al. A comparison of intravenous oxycodone and intravenous morphine in patient-controlled postoperative analgesia after laparoscopic hysterectomy. Anesth Analg 2009; 109: 1279-83.

3. Rygnestad T, Slørdal L. Morfin, petidin eller ketobemidon ved akutt smerte er det forskjeller av betydning? Tidsskr Nor Lægeforen 2000; 120: 2548-9.

4. Moksnes K, Kaasa S, Paulsen $\emptyset$ et al. Serum concentrations of opioids when comparing two switching strategies to methadone for cancer pain. Eur J Clin Pharmacol 2012; 68: 1147-56.

I Tidsskriftet nr. 12/2016 skrev jurist M. Hovland en kronikk om rettssikkerhet for den psykisk syke. Leder i Norsk psykiatrisk forening, A.K. Bergem, kom med et tilsvar i samme nummer, hvor hun trakk frem momenter for hvorfor tvangsbruken varierer i psykisk helsevern.

\section{Re: Rettstryggleik for den psykisk sjuke}

Jeg leste med stor interesse Marie Hovlands velskrevne kronikk vedrørende sprik i tvangsbruk ved ulike psykiatriske institusjoner og kontrollkommisjoner ut i fra et juridisk perspektiv (1). Et moment som jeg ut i fra en psykiatrisk synsvinkel synes det er verdt å legge til, er tolkning av psykosebegrepet som er inkludert i begrepet alvorlig sinnslidelse. Begrepet psykose har ingen entydig betydning/definisjon. Det eksisterer flere ulike definisjoner i de ulike oppslagsverk, diagnosemanualer og lærebøker. Den svært strikte definisjonen i ICD-10 er det for eksempel svært få som forholder seg til. Ulike leger/psykologer/kontrollkommisjoner kan således tolke pasienter med like symptomer svært forskjellig alt ettersom hvilken definisjon på psykose de velger å benytte. Dermed vil også vurderingen av pasienter med like symptomer variere og tvangsbruken variere.

Robert Rutskij

robert.rutskij@hotmail.com

Robert Rutskij (f. 1974) er spesialist i psykiatri ved Akershus universitetssykehus.

Ingen oppgitte interessekonflikter.

Litteratur

1. Hovland M. Rettstryggleik for den psykisk sjuke. Tidsskr Nor Legeforen 2016; 136: $1099-101$.

I Tidsskriftet nr. 18/2016 hadde J. Bjørke-Bertheussen og M.A. Weibell en kronikk om elektronisk tilgang til psykiatrisk journal for pasienter. De fikk svar av M. Storvik i nr. 21/2016. Forfatterne kommer her med et tilsvar.

\section{Re: Diskriminering er sjelden en gyllen middelvei}

Vi takker for kommentaren fra Marius Storvik vedrørende problemer knyttet til elektronisk pasientjournal (1). Vi kjenner oss imidlertid ikke igjen i kritikken.

Som vi utdyper i vårt tilsvar til Eva Cathrine Backer, er det nå avklart at i Helse Vest er tilbudet om elektronisk tilgang til journal et servicetilbud for pasientene. Det foreligger således ingen rett til klage. 